\title{
A comparative analysis of the attitudes of rural and urban consumers towards cultured meat
}

\author{
Elaine Shaw \\ Technological University Dublin \\ Máirtín Mac Con lomaire \\ Technological University Dublin, mairtin.macconiomaire@tudublin.ie
}

Follow this and additional works at: https://arrow.tudublin.ie/tfschafart

Part of the Marketing Commons, Recreation Business Commons, Social and Behavioral Sciences Commons, and the Tourism and Travel Commons

\section{Recommended Citation}

Shaw, E. and Mac Con lomaire, M. (2019), "A comparative analysis of the attitudes of rural and urban consumers towards cultured meat", British Food Journal, Vol. 121 No. 8, pp. 1782-1800. DOI: 10.1108/ BFJ-07-2018-0433

This Article is brought to you for free and open access by the School of Culinary Arts and Food Technology at ARROW@TU Dublin. It has been accepted for inclusion in Articles by an authorized administrator of ARROW@TU Dublin. For more information, please contact arrow.admin@tudublin.ie, aisling.coyne@tudublin.ie, gerard.connolly@tudublin.ie.

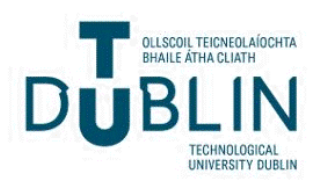


$\mathrm{BFJ}$

121,8

Received 31 July 2018 Revised 13 November 2018 Accepted 12 March 2019

\section{A comparative analysis of the attitudes of rural and urban consumers towards cultured meat}

\author{
Elaine Shaw and Máirtín Mac Con Iomaire \\ College of Arts and Tourism, \\ Technological University Dublin, Dublin, Ireland
}

\begin{abstract}
Purpose - The purpose of this paper is to perform a comparative analysis on the attitudes of rural and urban Irish consumers towards cultured meat.

Design/methodology/approach - A mixed methods exploratory sequential design was used. This involved collecting qualitative data first, through group interviews, and using the results of these to design the questionnaires for the quantitative data collection, which was analysed using SPSS $24.0 \AA$.

Findings - Urban consumers were more receptive towards cultured meat and more concerned about the environmental impact of current meat production practices. Rural consumers were more concerned about the possible damaging effect cultured meat production could have on agri-business and the livelihood of Irish farmers. The safety of the technology emerged as the biggest concern for both sets of consumers.

Research limitations/implications - The sample size used for the qualitative research resulted in a 95\% confidence level and a confidence interval of 5.55. A larger sample number would give a tighter confidence interval and a more accurate representation of consumers' attitudes.

Practical implications - This research could give guidance to food companies of how to market cultured meat products towards Irish consumers based on their concerns and their perceived benefits of the technology.

Social implications - This research added to previous research performed in Ireland showing that urban consumers are more receptive towards new food technologies than their rural counterparts.

Originality/value - This is the first paper comparing the attitudes of rural and urban Irish consumers towards cultured meat and adds to the literature on this emerging subject area.
\end{abstract}

Keywords Consumer attitudes, Republic of Ireland, Urban, Rural, Cultured meat

Paper type Research paper

\title{
1. Introduction
}

Cultured meat is meat which is produced outside of the animal of choice, through the culturing of stem cells which have been extracted from the animal (Bhat et al., 2015). This technology, originally researched for medical application (Post, 2014), holds the promise of what some researchers have labelled "vegetarian meat" in that it provides the possibility of meat without killing animals (Hopkins and Dacey, 2008). Cultured meat production has been proposed as a way of meeting the growing global demand for meat, while also substantially reducing pollution to the environment by dramatically cutting down on land, water and energy use which is currently required to produce meat (Pluhar, 2010; Bhat and Fayaz, 2011; Tuomisto and de Mattos, 2011). The biggest challenge facing the commercial success of cultured meat is with public perception and acceptance of the technology; as initial consumer reactions towards new food technologies are usually negative (Henchion et al., 2013). This initial repulsion consumers feel about an unfamiliar product, sometimes referred to as the "yuck factor", has been cited by researchers and in media coverage of the topic as a possible reason that consumers may reject the idea of cultured meat (Hopkins and Dacey, 2008; Pluhar, 2010; Goodwin and Shoulders, 2013). De Barcellos et al. (2010) found that consumers were strongly against any beef processing techniques which were perceived as "invasive". The further the technology was from a "natural" way of processing beef the more negative the response. Rozin (2005) demonstrated that the public's perception of the "naturalness" of a product is 
more related to the process the product undergoes than the content of the product. The manipulation of food or animals using techniques which would not occur naturally in nature has been shown to evoke major negative responses from consumers (Frewer et al., 2011; Siegrist and Sütterlin, 2017). Hocquette et al. (2015) found that educated consumers did not think that cultured meat was the solution to problems within the meat industry and were not convinced that artificial meat would be tasty, healthy and safe enough to be accepted by consumers. Recent studies have also shown that both gender (Wilks and Phillips, 2017) and age (Ward, 2017) affected how receptive consumers may be to this new technology.

\subsection{Ireland's meat industry}

The meat industry in Ireland is a significant source of employment, particularly in rural areas. The agri-food industry accounts for 8.6 per cent of total employment of the working population in Ireland (European Commission, 2017). It has been estimated that the meat industry directly employs over 10,000 people and a further 13,000 are involved in in-direct industries such as meat processing (Food Drink Ireland, 2017; Hanrahan, 2016). Beef production is vitally important to the Irish economy. It is an export dependent industry with over 90 per cent of the beef produced in Ireland in 2014 being exported (Hanrahan, 2016). Beef exports from Ireland in 2016 were worth €2.38bn (Bord Bia, 2018). Ireland's historic close relationship with cattle and the meat industry might influence how receptive Irish consumers would be towards cultured meat technology (Mac Con Iomaire and Gallagher, 2011).

\subsection{Rural vs urban consumers}

According to Sun and $\mathrm{Wu}$ (2004), rural consumers take longer than urban consumers to accept new products, placing them in the late adopter's category of consumers. The study also found them to be more price conscious than urban consumers. Cullen and Kingston (2009) further reinforced this as they found that urban Irish consumers were slightly more receptive to innovative food products than rural Irish consumers. Their study found that urban consumers rated quality as the most important factor in the purchasing of food products whereas rural consumers prioritised price.

Research on consumer attitudes to cultured meat to date has mostly been performed on consumers in urban areas (Post, 2014; Verbeke, Marcu, Rutsaert, Gaspar, Seibt, Fletcher and Barnett, 2015; Verbeke, Sans and Van Loo, 2015). This study set out to explore Irish consumers' attitudes towards the technology, with the aim of establishing if any significant differences exist between rural and urban consumers.

\section{Materials and methods}

\subsection{Framework}

Due to the limited existing data on consumer perception of cultured meat, the possible questions or concerns that the Irish public held about the technology was unknown. This justified the need to begin this research with the collection of qualitative data. A mixed methods exploratory sequential design approach was followed (Creswell, 2003), which involved collecting the qualitative data first by means of group interviews and using these data to design questionnaires which were then distributed to a large sample of people to collect the quantitative data. The study compared the responses from participants living in rural and urban areas. In Ireland urban areas are defined as towns and cities that contain 1,500 inhabitants or more, and areas containing less than this are considered rural (CSO, 2017). 
$\mathrm{BFJ}$

121,8

1784

\subsection{Group interviews design}

Purposive sampling was used to select participants for the group interviews allowing for the selection of participants who had characteristics of central importance to the research question. The primary selection criterion was that participants had to be meat eaters. It is recommended that groups share some homogeneity in terms of their background or a certain characteristic as it facilitates discussion by creating rapport among strangers and encourages participants to express themselves (Morgan, 1996; Patton, 2015). The location of the participants was an integral part of the research question so was a necessary segmentation factor. Age was chosen as a second homogenous factor. The following four groups were formed:

- Group 1: rural participants aged 18-34 (3 male and 3 female).

- Group 2: rural participants aged 35 or older (2 male and 4 female).

- Group 3: urban participants aged 18-34 (1 male and 4 female).

- Group 4: urban participants aged 35 or older (3 male and 3 female).

There were six participants in each of the groups except the young urban group which had to proceed with only five participants due to last minute cancellations. The gender composition of the groups is noted above.

A format consisting of ten questions was designed and asked of each of the groups. The groups began with an introduction of each of the participants and general questions regarding their purchasing preferences when it came to meat products. The topic of cultured meat was then introduced by a brief explanation followed by a short video of how a burger could be created though cultured meat technology. This video was carefully selected to be as impartial as possible. Following this, there were five more questions asked about cultured meat to determine what participants viewed as the possible advantages and disadvantages of the technology and if they would be willing to try it. They were asked what other products or technology that it reminded them of to assess what category they would place this product into, or perhaps remind them of another product which was greeted with apprehension when it was first released to the market. They were also asked what would instil trust in the product for them, to assess whether labelling and quality assurance stamps would have an influence on their choices.

\subsection{Qualitative data analysis}

The group interviews were audio recorded with consent from the participants and subsequently transcribed verbatim. The qualitative data were analysed using thematic analysis (Braun and Clarke, 2006). The main points raised under each question were compared against each other to identify the themes which were reoccurring in each of the groups. The main themes identified were used to formulate the questionnaire.

\subsection{Questionnaire design}

Google Forms was used to create the questionnaires (Appendix). A pilot survey was carried out before the final draft was released to the public. Participants were asked if they had ever heard of cultured meat. An information piece was provided about the technology along with an image which explained the process in a simple step by step format. Aside from questions regarding the respondents' demographics, the questionnaire was split into four key areas: meat consumption and purchasing behaviour, concerns about current meat production methods, comparing cultured meat to conventional meat and general opinion about cultured meat. For the purpose of conciseness and for clarity while discussing the questionnaire within this paper, it has 
been rearranged to remove the demographic questions and each question has been placed under its key area (see below).

Four key areas of questionnaire (adapted from the questionnaire in the Appendix).

(1) Meat consumption and purchasing behaviour:

- How often do you eat meat?

- Where would you buy your meat?

(2) Concerns with meat production methods:

- I am concerned about the environmental impact of current meat production methods.

- I buy organic meat where possible.

- I trust Irish meat more than meat from other countries.

(3) Comparison with conventional meat:

- Have you ever heard of cultured meat?

- Do you think cultured meat will be able to produce the same flavour and texture as conventional meat?

- Do you think cultured meat would be a premium product or an inferior product to conventional meat?

- How healthy do you think cultured meat would be in comparison with conventional meat?

- How appealing do you think cultured meat would be in comparison with conventional meat?

(4) General opinion about cultured meat:

- Cultured meat will become commonplace in the future.

- Science is interfering too much in the food chain.

- Cultured meat will be an artificial product.

- I would be willing to try cultured meat.

- Cultured meat would be a suitable meat option for vegetarians.

- Cultured meat would be more ethical than conventional meat.

- Rate the following concerns from 1 to 5 in the order which you think are of greatest concern ( $1=$ of greatest concern).

- Nutritional value of cultured meat.

- Unknown long-term health effects of consuming cultured meat.

- Damaging effect on agri-business and livelihood of farmers.

- Damaging effect on Irish beef industry and Irish economy.

- Lack of traceability of meat source.

- Rate the following potential benefits of cultured meat from 1 to 5 in the order which you think would be the most important ( $1=$ of greatest benefit):

- Animal welfare.

- Environmental benefits.
Attitudes of rural and urban

consumers

1785 
$\mathrm{BFJ}$

121,8

\subsection{Questionnaire distribution}

The target was to achieve 400 responses as this would allow for a 95\% confidence level and a confidence interval of 5; this would allow the results to be generalised to the Irish population. A convenience sampling approach was adopted. Dublin (urban), Westmeath (rural) and Galway (city-urban, county-rural) were the main geo-demographic regions used to obtain responses due to the researchers' contacts and familiarity with these areas. Due to the time restrictions of the research, the data collection had to stop before reaching the target of 400 responses. In total, 312 valid responses were acquired, evenly split between geo-demographics, gender and age. This reduced sample size resulted in a $95 \%$ confidence level and a confidence interval of 5.55 .

\subsection{Quantitative data analysis}

The statistical data analysis software package SPSS $24.0{ }^{\circledR}$ was used to analyse the quantitative data. Pearson's $\chi^{2}$ tests were carried out on the nominal data, and independent sample $t$-tests were conducted on the ordinal data collected to assess if there were any significant differences between the responses of rural and urban consumers. The probability value ( $p$-value) indicates the significance of the results. Results with $p<0.05$ are statistically significant, indicating a confidence level of $>95$ per cent (Weiss, 2008). Cramérs V was calculated using the SPSS software to measure the effect size of statistically significant results from the $\chi^{2}$ tests. Cohen's $d$ was calculated for any results of the independent sample $t$ tests which were found to be significantly different, to establish how big or small the significant difference was. Cohen's $d$ was calculated using the following formula:

$$
d=\frac{M_{1}-M_{2}}{\text { SD pooled }}
$$

The magnitude of effect sizes for Cramérs $V$ was small effect (0.1), moderate effect (0.3) and large effect (0.5), and for Cohen's $d$ was small effect (0.2), moderate effect (0.5) and large effect (0.8)(adapted from Cohen, 1988, pp. 25, 79).

For both the $\chi^{2}$ tests and the independent $t$ tests the following hypotheses were assessed:

HO. There are no significant differences between the responses of rural and urban consumers.

H1. There are significant differences between the responses of rural and urban consumers.

\section{Results}

The five main themes identified from the thematic analysis of the qualitative data are outlined in detail below. Within Table I, the coding (G2F, R) refers to Group 2, female and rural, whereas (G4M, U) refers to Group 4, male and urban.

\subsection{Theme 1: feeling that cultured meat is unnatural}

During the group interviews, the words "unnatural", "artificial", "false" or "fake" were used frequently to describe cultured meat (see Table I, A-D). In line with research by Rozin (2005) which demonstrated that peoples' perception of the "naturalness" of a product is more related to the process the product undergoes than the content of the product, participants felt that it was the process of creating cultured meat which was unnatural (see Table I, E, F). 
A "Fake... not real food" (G3F, U)

B "Interfering with nature, false food" (G2F, R)

C "Totally unnatural, would not entertain it and would not eat it" (G2M, R)

D "Unnatural artificial food resource" (G1F, R)

E "It's an unnatural way of doing it [processing meat]" (G4M, U)

F "Science interfering with nature and the natural running of things" (G2M, R)

$\mathrm{G}$ "I don't know if I would want to be a consistent buyer of it, because you feel like you wouldn't be supporting the Irish farmers" (G3F, U)

$\mathrm{H}$ "My heart would hate to see it taking off" (G2F, R)

I "What about our exports? A lot of people value Irish beef products" (G1F, R)

$\mathrm{J}$ "[cultured meat would] kill the agribusiness" (G2F, R)

$\mathrm{K}$ "The collapse of our... dairy and meat industry" (G4F, U)

$\mathrm{L}$ "What are they [farmers] going to do for a living now?" (G3F, U)

M "Where does the poor farmer come at the end of it?" (G1M, R)

$\mathrm{N}$ "I would say Irish beef is safer" (G2F, R)

O "Ireland has the best traceability of anywhere that I know of" (G1M, R)

$P$ "I'd only buy Irish [meat]" (G4F, U)

Q "When you're abroad... meat's never the same!" (G2F, R)

$\mathrm{R}$ "I just expect that the cows [in Ireland] are being reared as they should have been" (G3M, U)

$\mathrm{S}$ "I think we feel that in Irish factories there's some controls, whereas if it comes in from outside [of Ireland] you don't know what control is on it" (G4M, U)

$\mathrm{T}$ "I know it's bad abroad, I've heard of cattle herds nearly raised like chickens... knowing very little about the subject I'd think Irish methods are probably ok" (G1M, R)

$\mathrm{U}$ "You're not thinking that Irish farmers are filling them with hormones" (G3F, U)

$\mathrm{V}$ "We trust our farmers" (G2M, R)

Notes: G2M, R means Group 2, male and rural; G4F, U means Group 4, female and urban

Table I.

Quotes from group interview participants highlighting themes 1-3

\subsection{Theme 2: concern for the Impact on Irish farmers and Irish economy}

There was an element of guilt attached to being in favour of cultured meat due to the potential detrimental effect it may have on Irish farmers. There was strong awareness in the group interviews of the importance of the beef industry to the Irish economy, and participants expressed concern that cultured meat production may have a damaging effect on this industry and that by buying the product you would not be supporting Irish farmers (see Table I, G-K). Participants expressed fear that farmers would lose their livelihood due to cultured meat (see Table I, L, M). One participant mused "Where does the poor farmer come at the end of it?" (Table I, M).

\subsection{Theme 3: greater trust in Irish produced meat}

A common theme that emerged from each of the groups was that traceability was important. Participants felt that meat which was produced in Ireland was of a higher standard than non-Irish meat (see Table I, N-Q). Participants expressed cynical attitudes towards meat products which were not produced in Ireland. There was a feeling that the mistreatment of animals and the use of substances such as hormones and antibiotics which has been associated with the meat industry does not occur in Ireland, and that these are practices that only occur abroad (see Table I, R-V).

\subsection{Theme 4: concern about the safety of cultured meat}

In each of the groups, participants feared that because the technology is so new, the long-term health effects that consuming cultured meat products may have on humans are unknown and could be detrimental to health. "I'd wonder that if years down the line it would come out that oh actually that process we were doing causes cancer" (see Table II, A-D). 
$\mathrm{BFJ}$

121,8

1788

Table II.

Quotes from group interview participants highlighting themes 4 and 5
A "I'd wonder that if years down the line it would come out that oh actually that process we were doing causes cancer" (G1M, R)

B "We don't know the long-term effects on us" (G3F, U)

C "The uncertainty and the side effects of eating something manufactured like that" (G4F, U)

D "There's too much unknown about it" (G2M, R)

E "They could throw anything into it after a while" (G4F, U)

F "Who's to say that they've picked a good cut... and haven't thrown something else into the mix along the way" (G3F, U)

G "It will start off being handled well, but then people will abuse it" (G4M, U)

$\mathrm{H}$ "Was it produced in Ireland or was it packaged in Ireland? I only heard something from the weekend about [companies] putting the Irish flag on things and it's not Irish at all" (G4F, U)

I "There was this meat packaging place I think it was down in Cork that was saying "oh yeah 100\% Irish beef" but the stuff was being imported from Argentina but because they were packaging it in Cork they were allowed to call it $100 \%$ Irish beef" (G1M, R)

$\mathrm{J}$ "A way for them to charge you more money" (G2F, R)

$\mathrm{K}$ "Sure you never know for sure [if the meat is truly organic]" (G1M, R)

L "I've heard so many conflicting stories that "oh this is organic" but then you hear it's not organic at all... I wouldn't really trust it” (G1M, R).

M "I wouldn't definitely believe that everything [that is labelled organic] is pure organic" (G2M, R)

Notes: G2M, R means Group 2, male and rural; G4F, U means Group 4, female and urban

\subsection{Theme 5: distrust in food companies and labelling}

Participants believed that companies producing cultured meat could start manipulating it unknown to consumers (see Table II, E-G). Consumers are becoming more sceptical about food labelling due to news stories about deceptive labelling techniques (see Table II, H, I). This was especially clear in the two rural group interviews when it came to discussions about labelling organic meat products. There was cynicism over the use of the word "organic" on meat labels. The participants in the rural groups felt that it was merely a marketing ploy to charge more money for meat (see Table II, J-M).

\subsection{Quantitative results}

A total of 312 valid responses were acquired using a convenience sampling approach. Rural and urban areas were evenly represented, and an even number of responses was received from each of the six age categories. Table III shows the breakdown of the demographics of the population sample.

For greater clarity in the results section of this paper, the survey question numbers relate to the question numbers as outlined in the list of "key areas of the questionnaire". The alternative hypothesis was proven in five of the ordinal questions, as the results of the $t$-tests found significant differences between responses from rural and urban consumers (see Table IV for summary of responses and the significant effect sizes). Rural consumers were found to be more frequent consumers of meat, with 74 per cent of rural respondents stating they eat meat at least once a day, in comparison to 51 per cent of urban consumers. Urban consumers were found to be more concerned about current meat production practices than rural consumers. Over 47 per cent of urban consumers stated they were concerned about the environmental effects of current meat production methods compared to just over 36 per cent of rural respondents. In total, 47 per cent of urban consumers believe that cultured meat would be more ethical than conventional meat while only 33 per cent of rural consumers agreed. Urban consumers emerged as more likely to purchase organic meat than rural consumers. A higher percentage of rural consumers believe that cultured meat will not become commonplace in the future, while urban consumers are more expectant that it will become the norm. Urban consumers were more willing to try cultured meat with 62 per cent stating they would try it in comparison to just 


\begin{tabular}{|c|c|c|c|c|c|}
\hline \multirow[t]{2}{*}{ Demographic } & \multicolumn{2}{|l|}{ Rural } & \multicolumn{2}{|c|}{ Urban } & \multirow{3}{*}{$\begin{array}{r}\text { Attitudes of } \\
\text { rural and } \\
\text { urban }\end{array}$} \\
\hline & Sample number & $\%$ & Sample number & $\%$ & \\
\hline Gender & & & & & \\
\hline Male & 78 & 25 & 78 & 25 & consumers \\
\hline Female & 78 & 25 & 78 & 25 & \\
\hline \multicolumn{5}{|l|}{ Age category } & 1789 \\
\hline $15-24$ & 26 & 8.33 & 26 & 8.33 & \\
\hline $25-34$ & 26 & 8.33 & 26 & 8.33 & \\
\hline $35-44$ & 26 & 8.33 & 26 & 8.33 & \\
\hline $45-54$ & 26 & 8.33 & 26 & 8.33 & \\
\hline $55-64$ & 26 & 8.33 & 26 & 8.33 & \\
\hline $65+$ & 26 & 8.33 & 26 & 8.33 & \\
\hline \multicolumn{6}{|l|}{ Education level } \\
\hline Primary education & 12 & 7.7 & 8 & 5.1 & \\
\hline Secondary education & 34 & 21.8 & 19 & 12.2 & \\
\hline Apprenticeship/ trade & 17 & 10.9 & 13 & 8.3 & \\
\hline Third-level certification & 27 & 17.3 & 10 & 6.4 & \\
\hline Undergraduate degree & 44 & 28.2 & 58 & 37.2 & \\
\hline Postgraduate degree & 22 & 14.1 & 48 & 30.8 & \\
\hline \multicolumn{6}{|l|}{ Occupation } \\
\hline Self-employed/ Freelance & 21 & 13.5 & 17 & 10.9 & \\
\hline Farmer & 16 & 10.3 & 0 & 0 & \\
\hline White collar/civil servant & 45 & 28.8 & 63 & 40.4 & \\
\hline Housewife/househusband & 9 & 5.8 & 10 & 6.4 & \\
\hline Skilled worker & 29 & 18.6 & 29 & 18.6 & \\
\hline Student & 18 & 11.5 & 15 & 9.6 & \\
\hline Pensioner & 15 & 9.6 & 19 & 12.2 & \\
\hline Currently without work & 2 & 1.3 & 0 & 0 & \\
\hline Other & 1 & 0.6 & 3 & 1.9 & \\
\hline \multicolumn{6}{|l|}{ Disposable income } \\
\hline$€ 50$ & 27 & 17.3 & 16 & 10.3 & \\
\hline$€ 100$ & 47 & 30.1 & 26 & 16.7 & Table III. \\
\hline$€ 150$ & 26 & 16.7 & 46 & 29.5 & Demographics of \\
\hline$€ 200+$ & 56 & 35.9 & 68 & 43.6 & survey respondents \\
\hline
\end{tabular}

\begin{tabular}{|c|c|c|c|c|c|c|c|c|c|c|}
\hline \multirow[b]{2}{*}{ Q } & \multicolumn{2}{|c|}{ Rural } & \multicolumn{2}{|c|}{ Urban } & \multirow[b]{2}{*}{ df } & \multirow[b]{2}{*}{$t$} & \multirow[b]{2}{*}{$p$-value } & \multirow[b]{2}{*}{ Cohen's $d$} & \multirow[b]{2}{*}{ Significant difference } & \\
\hline & Mean & SD & Mean & $\mathrm{SD}$ & & & & & & \\
\hline 1 & 0.33 & 0.626 & 0.66 & 0.799 & 293 & -4.023 & $<0.001$ & 0.46 & Yes & \\
\hline 3 & 2.12 & 0.959 & 2.39 & 1.081 & 306 & -2.326 & 0.021 & 0.26 & Yes & \\
\hline 4 & 1.71 & 1.158 & 2.10 & 1.224 & 310 & -2.897 & 0.004 & 0.33 & Yes & \\
\hline 5 & 3.39 & 0.987 & 3.33 & 1.042 & 310 & 0.558 & 0.577 & $\mathrm{n} / \mathrm{a}$ & No & \\
\hline 9 & 1.28 & 1.189 & 1.53 & 1.121 & 310 & -1.960 & 0.051 & $\mathrm{n} / \mathrm{a}$ & No & \\
\hline 10 & 0.62 & 1.025 & 0.69 & 0.949 & 310 & -0.630 & 0.529 & $\mathrm{n} / \mathrm{a}$ & No & \\
\hline 11 & 1.94 & 1.190 & 2.33 & 1.012 & 302 & -3.179 & 0.002 & 0.35 & Yes & \\
\hline 12 & 2.63 & 1.170 & 2.40 & 1.082 & 310 & 1.859 & 0.064 & $\mathrm{n} / \mathrm{a}$ & No & \\
\hline 13 & 2.94 & 0.985 & 2.85 & 0.958 & 310 & 0.874 & 0.383 & $\mathrm{n} / \mathrm{a}$ & No & Table IV. \\
\hline 14 & 1.94 & 1.311 & 2.38 & 1.236 & 310 & -3.065 & 0.002 & 0.35 & Yes & Summary of $t$-test \\
\hline 15 & 1.86 & 1.327 & 1.91 & 1.307 & 310 & -0.344 & 0.731 & $\mathrm{n} / \mathrm{a}$ & No & results on ordinal \\
\hline 16 & 1.92 & 1.242 & 2.13 & 1.186 & 310 & -1.538 & 0.125 & $\mathrm{n} / \mathrm{a}$ & No & questions from survey \\
\hline
\end{tabular}


$\mathrm{BFJ}$

121,8

1790

46 per cent of rural consumers. Both sets of consumers (74 per cent of all respondents) thought cultured meat would be an artificial product.

Both sets of consumers believed that cultured meat would be an inferior product to conventional meat and would expect to pay less money for it. In total, 89 per cent of all respondents felt that cultured meat would not be able to produce the same flavour and texture as conventional meat.

When asked to rate their biggest concerns about cultured meat technology, the responses of rural and urban consumers differed in two of the concerns (Table V). The alternative hypothesis was proven for the concern of "damaging effect on agri-business and livelihood of farmers" (Pearson's $\chi^{2}$ with $4 \mathrm{df}=12.045, p=0.017$, Cramers V $=0.196$ ). This was found to be a bigger concern for rural respondents, with 44 per cent of rural respondents rating this in their top two biggest concerns in comparison to 29 per cent of urban consumers. The alternative hypothesis was also proven for the concern of "unknown long-term health effects of consuming cultured meat" (Pearson's $\chi^{2}$ with 4 $\mathrm{df}=11.644, p=0.020$, Cramér's $\mathrm{V}=0.193$ ). In total, 66 per cent of urban consumers rated this within their top two biggest concerns in comparison to 58 per cent of rural consumers. The Cramér's V for both concerns showed that effect size of these differences is small. The null hypothesis was proven for all the benefits listed in Q.18 of the survey showing that both sets of consumers had similar views on what they regarded the most important potential benefit of cultured meat.

3.6.1 Cross-tabulation of other demographics. Cross-tabulations were performed across a range of demographics which had been assessed in the survey. There were no statistically significant results from any of the categories relating to the education or income of respondents. Statistically significant differences were uncovered relating to the gender and ages of respondents for the question - "would you be willing to try cultured meat?" There was a statistically significant difference between the responses of men and women (Pearson's $\chi^{2}$ with $4 \mathrm{df}=13.906, p=0.008$ ). In total, 63 per cent of Irish men stated they would be willing to try cultured meat as opposed to just 46 per cent of women. There was

\begin{tabular}{|c|c|c|c|c|c|}
\hline Question & $\begin{array}{l}\text { Pearson } \\
\chi^{2} \text { value }\end{array}$ & df & $p$-value & $\begin{array}{c}\text { Cramér's } \\
\text { V }\end{array}$ & $\begin{array}{l}\text { Hypothesis proven } \\
\text { (null or alternative) }\end{array}$ \\
\hline \multicolumn{6}{|l|}{ Nominal questions } \\
\hline Q.2 & 2.061 & 3 & 0.560 & $\mathrm{n} / \mathrm{a}$ & Null \\
\hline Q.6 & 0.071 & 1 & 0.790 & $\mathrm{n} / \mathrm{a}$ & Null \\
\hline Q.7 & 3.100 & 2 & 0.212 & $\mathrm{n} / \mathrm{a}$ & Null \\
\hline Q.8 & 0.351 & 2 & 0.839 & $\mathrm{n} / \mathrm{a}$ & Null \\
\hline \multicolumn{6}{|l|}{ Q.17 Benefits } \\
\hline Nutritional value of cultured meat & 5.347 & 4 & 0.254 & $\mathrm{n} / \mathrm{a}$ & Null \\
\hline $\begin{array}{l}\text { Unknown long-term health effects of consuming } \\
\text { cultured meat }\end{array}$ & 11.644 & 4 & 0.020 & 0.193 & Alternative \\
\hline $\begin{array}{l}\text { Damaging effect on agri-business and the livelihood } \\
\text { of farmers }\end{array}$ & 12.045 & 4 & 0.017 & 0.196 & Alternative \\
\hline $\begin{array}{l}\text { Damaging effect on Irish beef industry and Irish } \\
\text { economy }\end{array}$ & 2.814 & 4 & 0.589 & $\mathrm{n} / \mathrm{a}$ & Null \\
\hline Lack of traceability of meat source & 3.572 & 4 & 0.467 & $\mathrm{n} / \mathrm{a}$ & Null \\
\hline \multicolumn{6}{|l|}{ Q.18 Concerns } \\
\hline Animal Welfare Environmental benefits & 3.848 & 4 & 0.427 & $\mathrm{n} / \mathrm{a}$ & Null \\
\hline Antibiotic and hormone free meat & 5.746 & 4 & 0.219 & $\mathrm{n} / \mathrm{a}$ & Null \\
\hline Nutritionally controlled meat & 5.142 & 4 & 0.273 & $\mathrm{n} / \mathrm{a}$ & Null \\
\hline Way of "feeding the world"/ Lasting supply of meat & 3.939 & 4 & 0.414 & $\mathrm{n} / \mathrm{a}$ & Null \\
\hline
\end{tabular}

Table V.

Summary of Pearson $\chi^{2}$ results on rural vs urban consumers
Way of "feeding the world"/ Lasting supply of meat 
also a statistically significant relationship between the age of respondents and their willingness to try cultured meat (Pearson's $\chi^{2}$ with $20 \mathrm{df}=48.119, p=0.000$ ). The younger age categories were more willing to try cultured meat, with the level of disagreement with this statement rising as the age of respondents increased.

\section{Discussion}

The aim of this study was to compare the attitudes of rural and urban consumers towards cultured meat. Urban consumers were more concerned than rural consumers about the ethics and environmental impact of conventional meat production methods. As rural consumers are in closer proximity to agricultural areas and more likely to be involved in the agri-business, they may be more defensive of its practices and therefore less likely to question the methods of current meat production systems. This may also be a factor in why the possible disadvantage of "damaging effect on agri-business and the livelihood of farmers" was found to be a bigger concern for rural respondents. As farmers reside in rural areas and an important source of employment in rural areas is in the agri-business sector (Department of Agriculture, Food and the Marine, 2016), this would mean that this would be a potential disadvantage that would more directly impact residents of rural areas.

The results highlighted that urban consumers were more receptive to the concept of cultured meat than their rural counterparts. They are more willing to try cultured meat and are more likely to believe that cultured meat will become commonplace in the future. This is in line with previous research carried out in Ireland which showed that urban consumers are more receptive towards new food products than rural consumers (Cullen and Kingston, 2009).

Men were found to be much more willing to try cultured meat than women. It has been shown in previous studies that women show more negative views towards novel food technologies (Cox et al., 2007; Bonar, 2014). These results also aligned with consumer research carried out in the USA which found men to be more receptive of cultured meat (Wilks and Phillips, 2017). Age was also deemed to be significant as the under $35 \mathrm{~s}$ were much more willing to try cultured meat in comparison to the over $55 \mathrm{~s}$. This backed up a recent study in the UK which showed that consumers over 55 are the least likely to buy cultured meat (Ward, 2017).

\subsection{Marketing implications}

The results of this research could give guidance to food companies of how to approach the introduction of cultured meat products onto the Irish market. It will be important for the food industry to emphasise the potential benefits that most matter to Irish consumers. The environmental benefits of cultured meat would need to be emphasised as this emerged as the most important potential benefit by Irish consumers. The biggest concerns of Irish consumers would need to be addressed and consumers would need to be provided with the appropriate information to ensure them of the safety and nutritional value of the products.

As rural consumers were found to consume meat more frequently than urban consumers, they would be a key demographic for food companies to convince to buy cultured meat. The results from the focus groups found that rural consumers were more sceptical towards labelling so food companies would need to be more proactive about convincing this set of consumers to purchase cultured meat products. These results aligned with research from Cullen and Kingston (2009) and Sun and Wu (2004) which found rural consumers to be more suspicious of mass advertising and less influenced by modes of advertising than urban consumers.
Attitudes of rural and urban

consumers 
$\mathrm{BFJ}$

121,8

1792

\subsection{Recommendations for future research}

This study was only conducted on Irish consumers who consumed meat, so a further area of research would be to carry out a similar study on vegetarians in Ireland to assess their opinions on cultured meat. Their opinions would be valuable as it would highlight whether vegetarians would be a possible target market for cultured meat products (see Hopkins and Dacey, 2008). This study compared the responses of consumers based on their current residence, but it did not consider where the respondents were originally from. Further research could consider participants geo-demographic backgrounds, or that of their parents, to assess if this influenced their opinions. As the study failed to meet its original target of 400 valid survey respondents, a similar study could be repeated on a larger scale to obtain a tighter confidence interval and thus a more accurate representation of consumers' attitudes.

\section{Conclusion}

This study highlighted key differences between the attitudes and behaviours of rural and urban Irish consumers towards conventional and cultured meat. Rural consumers were more frequent consumers of meat while urban consumers bought more organic meat. Urban consumers were found to be more concerned about the environmental and ethical considerations of conventionally produced meat which may be why they are more likely to purchase organic meat and are also more open to trying alternative products. Rural consumers were found to be less willing to try cultured meat. The combined results of the qualitative and quantitative research synthesised to the general feeling that cultured meat would be an unnatural and artificial product. Changing consumers' perception of this would be a significant stumbling block for the acceptance of this technology. Cultured meat will need to be able to mimic conventionally produced meat in appearance, taste, texture and nutritional value, to make it appealing to consumers (Hocquette et al., 2015). Gaining the trust of consumers is vital for the success of new food technologies. Initial consumer reactions towards new food technologies are generally negative (Henchion et al., 2013), especially if they do not understand the mechanisms and applications of the technology (Frewer et al., 2011). As the technology becomes closer to producing commercial products, it is vital that consumers are provided with sufficient information about the process of culturing meat so that they can understand the technology, as increased understanding may increase its chances of commercial success.

\section{References}

Bhat, Z.F. and Fayaz, H. (2011), "Prospectus of cultured meat - advancing meat alternatives", Journal of Food Science and Technology, Vol. 48 No. 2, pp. 125-140.

Bhat, Z.F., Kumar1, S. and Fayaz, H. (2015), "In vitro meat production: challenges and benefits over conventional meat production", Journal of Integrative Agriculture, Vol. 14 No. 2, pp. 241-248.

Bonar, A. (2014), " $40 \%$ of Brits ready to try insects: Canadean report", Food Navigator 23 July, available at: www.foodnavigator.com/Market-Trends/Insects-40-of-UK-consumers-are-willingto-try-them-says-Canadean (accessed 24 August 2017).

Bord Bia (2018), "Factsheet on the Irish agricultural and food and drink sector", Bord Bia, available at: www.bordbia.ie/industry/buyers/industryinfo/agri/pages/default.aspx (accessed 4 January 2018).

Braun, V. and Clarke, V. (2006), "Using thematic analysis in psychology", Qualitative Research in Psychology, Vol. 3 No. 2, pp. 77-101.

Cohen, J. (1988), Statistical Power Analysis for the Behavioural Sciences, 2nd ed., Lawrence Earlbaum Associates, Hilsdale, NJ. 
Cox, D.N., Evans, G. and Lease, H.J. (2007), "The influence of information and beliefs about technology on the acceptance of novel food technologies: a conjoint study of farmed prawn concepts", Food Quality and Preference, Vol. 18 No. 5, pp. 813-823.

Creswell, J.W. (2003), Research Design: Qualitative, Quantitative, and Mixed Methods Approaches, 2nd ed., Sage Publications Inc, Thousand Oaks, CA.

CSO (2017), Census 2016 Results - Part 1, Central Statistics Office, Cork.

Cullen, F. and Kingston, H. (2009), "Analysis of rural and urban consumer behaviour toward new food products using a food-related lifestyle instrument", Journal of Foodservice Business Research, Vol. 12 No. 1, pp. 18-41.

De Barcellos, M.D., Kugler, J.O., Grunert, K.G., Van Wezemael, L., Perez-Cueto, F.J., Ueland, O. and Verbeke, W. (2010), "European consumers' acceptance of beef processing technologies: a focus group study", Innovative Food Science \& Emerging Technologies, Vol. 11 No. 4, pp. 721-732.

Department of Agriculture, Food and the Marine (2016), Annual Review \& Outlook for Agriculture, Food and the Marine 2015-2016, Department of Agriculture, Food and the Marine, Dublin, available at: www.agriculture.gov.ie/media/migration/publications/2016/AnnualReviewOutlook20152016200 716.pdf (accessed 26 May 2017).

European Commission (2017), Key EU Policies for Ireland - Agriculture, European Commission, Dublin, available at: http://ec.europa.eu/ireland/news/key-eu-policy-areas/agriculture_en (accessed 30 May 2017).

Food Drink Ireland (2017), "Meat industry overview”, Food Drink Ireland, Dublin, available at: www. fooddrinkireland.ie/Sectors/FDII/FDII.nsf/vPages/Meat meat-industry-overview?OpenDocument (accessed 30 May 2017).

Frewer, L.J., Bergmann, K., Brennan, M., Lion, R., Meertens, R., Rowe, G., Siegrist, M. and Vereijken, C. (2011), "Consumer response to novel agri-food technologies: implications for predicting consumer acceptance of emerging food technologies", Trends in Food Science and Technology, Vol. 22 No. 8, pp. 442-456.

Goodwin, J.N. and Shoulders, C.W. (2013), "The future of meat: a qualitative analysis of cultured meat media coverage", Meat Science, Vol. 95 No. 3, pp. 445-450.

Hanrahan, K. (2016), “The significance of beef”, Teagasc available at: www.teagasc.ie/media/website/ publications/2016/Beef-Manual-Section1.pdf (accessed 30 May 2017).

Henchion, M., McCarthy, M., Williams, G., Greehy, G., McCarthy, S., Dillon, E. and Kavanagh, G. (2013), "Irish consumer and industry acceptance of novel food technologies: research highlights, implications and recommendations", FIRM Research funded by the Department of Agriculture, Food and the Marine, Teagasc Food Research Centre, University College Cork and Dublin Institute of Technology, Dublin, available at: www.teagasc.ie/publications/view_publication. aspx?publicationID= 2919 (accessed 22 August 2017).

Hocquette, A., Lambert, C., Sinquin, C., Peterolff, L., Wagner, Z., Bonny, S.P.F. and Hocquette, J. (2015), "Educated consumers don't believe artificial meat is the solution to the problems with the meat industry", Journal of Integrative Agriculture, Vol. 14 No. 2, pp. 273-284, doi: 10.1016/S2095-3119(14)60886-8.

Hopkins, P.D. and Dacey, A. (2008), "Vegetarian meat: could technology save animals and satisfy meat eaters?", Journal of Agricultural and Environmental Ethics, Vol. 21 No. 6, pp. 579-596.

Mac Con Iomaire, M. and Gallagher, P. (2011), "Irish corned beef: a culinary history", Journal of Culinary Science \& Technology, Vol. 9 No. 1, pp. 27-43, doi: 10.1080/15428052.2011.558464.

Morgan, D.L. (1996), "Focus groups", Annual Review of Sociology, Vol. 22 No. 1, pp. 12-152.

Patton, M.Q. (2015), Qualitative Research and Evaluation Methods, 4th ed., SAGE, Thousand Oaks, CA.

Pluhar, E.B. (2010), "Meat and morality: alternatives to factory farming", Journal of Agricultural and Environmental Ethics, Vol. 23 No. 5, pp. 455-468.

Post, M.J. (2014), "Cultured beef, medical technology to produce food", Journal of the Science of Food and Agriculture, Vol. 94 No. 6, pp. 1039-1041.
Attitudes of rural and urban

consumers

1793 
$\mathrm{BFJ}$

121,8

1794

Rozin, P. (2005), “The meaning of 'natural': process more important than content", Psychological Science, Vol. 16 No. 8, pp. 652-658.

Siegrist, M. and Sütterlin, B. (2017), "Importance of perceived naturalness for acceptance of food additives and cultured meat", Appetite, Vol. 113, June, pp. 320-326.

Sun, T. and Wu, G. (2004), "Consumption patterns of Chinese urban and rural consumers", Journal of Consumer Marketing, Vol. 21 No. 4, pp. 245-253.

Tuomisto, H.L. and de Mattos, M.J. (2011), "Environmental impacts of cultured meat production", Environmental Science \& Technology, Vol. 45 No. 14, pp. 6117-6123.

Verbeke, W., Sans, P. and Van Loo, E.J. (2015), "Challenges and prospects of consumer acceptance of cultured meat", Journal of Integrative Agriculture, Vol. 14 No. 2, pp. 285-294.

Verbeke, W., Marcu, A., Rutsaert, P., Gaspar, R., Seibt, B., Fletcher, D. and Barnett, J. (2015), “'Would you eat cultured meat': consumers reactions and attitude formation in Belgium, Portugal and the United Kingdom”, Meat Science, Vol. 102, April, pp. 49-58.

Ward, C. (2017), "Attitudes towards cultured meat", Harris Interactive, London, 8 March, available at: http://harris-interactive.co.uk/attitudes-towards-cultured-meat/ (accessed 30 August 2017).

Weiss, N. (2008), Introductory Statistics, 8th ed., Pearson Education, San Francisco, CA.

Wilks, M. and Phillips, C.J. (2017), "Attitudes to in vitro meat: a survey of potential consumers in the United States", PLoS One, Vol. 12 No. 2, p. e0171904, available at: https://doi.org/10.1371/ journal.pone.0171904 
Appendix. Questionnaire

Irish consumer attitudes towards cultured meat * Required

1. Do you live in a rural or urban area? * Mark only one oval.

Rural

Urban

2. Please specify the area where you live (If urban name the city or town, if rural name the village or area) *

3. What is your gender? *

Mark only one oval.

\section{Female}

Male

4. What age bracket do you fall into? *

Mark only one oval.

18-24

25-34

$35-44$

$45-54$

$55-64$

$65+$

5. Highest level of education reached? * Mark only one oval.

Primary education

Secondary education

Apprenticeship/ trade qualification

Third level certification (level 6)

Undergraduate degree (level 7 or 8 )

Postgraduate degree (level 9 or 10 )
Attitudes of

rural and

urban

consumers

1795 
BFJ

121,8

1796
6. Do you eat meat? (If no, terminate questionnaire, if yes continue) * Mark only one oval.

Yes

No

7. How often do you eat meat? *

Mark only one oval.

At least once a day

At least once every 2 days

At least once a week

Less than once a week

8. Where would you usually buy your meat? *

Mark only one oval.

Butchers

Supermarket

Farmers market

Other:

9. Tick each of the factors that would effect the choice of meat that you buy: Check all that apply.

Price- cheaper products

Price- more expensive products

Origin of the meat

Leanness

Colour

Sell by date which is furthest away

Brand name

Quality assurance labels

Appealing packaging

Other:

10. Of each of the factors listed above, which would be the most important factor to you when buying meat? * 
11. Please indicate whether or not you agree with the following statements: *

Attitudes of

Mark only one oval per row.

rural and

urban

strongly disagree neither agree nor agree strongly

consumers

I'm concerned about the environmental impact of current meat production disagree

methods

I buy organic meat

products where possible

I trust Irish meat more than

meat from other countries

12. Have you ever heard of cultured meat? (If no, please read information piece below) *

Mark only one oval.

Yes

No

\section{Cultured meat explained:}

Cultured meat is a way of producing meat outside of the animal, without killing the animal. Stem cells are extracted from the animal of choice, without harming the animal, and these cells are then grown into muscle tissue in a culture media in a lab. This muscle tissue is biologically the same as the muscle tissue that would be made inside the animal. The muscle tissues can then be used to create meat products.

If you would like a more in depth explanation please see the video below:

\section{example of how beef burgers can be produced using the process of cultured meat:}

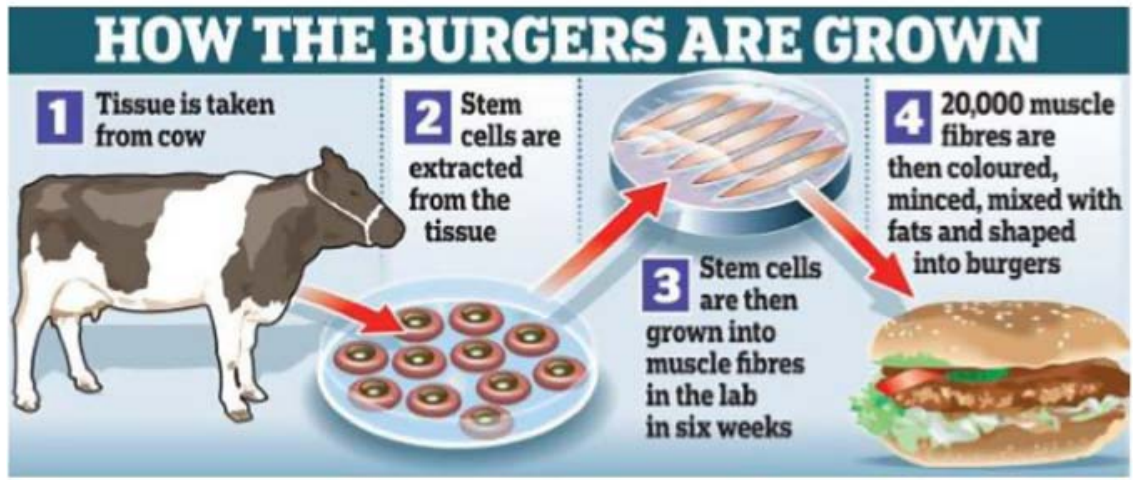


$\mathrm{BFJ}$ 121,8

1798

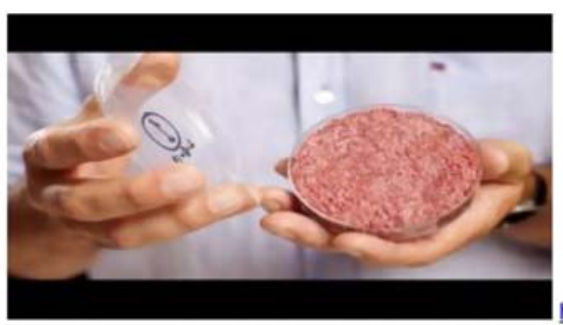

http: $/ /$ youtube.com/watch?v=gyxPxcE_4to

13. Please tick your answers to the following questions. Note: Conventional meat is meat as we know it at the moment, produced the traditional way. "

Mark only one oval per row.

How healthy do you think
less
cultured meat would be in
comparison with
conventional meat?
How appealing do you think
cultured meat is in
comparison to conventional
meat?

14. Please indicate whether or not you agree with the following statements *

Mark only one oval per row.

\begin{tabular}{|c|c|c|c|c|c|}
\hline & $\begin{array}{l}\text { Strongly } \\
\text { disagree }\end{array}$ & Disagree & $\begin{array}{l}\text { Neither agree nor } \\
\text { disagree }\end{array}$ & Agree & $\begin{array}{c}\text { Strongly } \\
\text { agree }\end{array}$ \\
\hline $\begin{array}{l}\text { Cultured meat will become } \\
\text { commonplace in the future }\end{array}$ & & & & & \\
\hline $\begin{array}{l}\text { Science is interfering too } \\
\text { much in the food chain }\end{array}$ & & & & & \\
\hline $\begin{array}{l}\text { Cultured meat will be an } \\
\text { artificial product }\end{array}$ & & & & & \\
\hline $\begin{array}{l}\text { I would be willing to try } \\
\text { cultured meat }\end{array}$ & & & & & \\
\hline $\begin{array}{l}\text { Cultured meat would be a } \\
\text { suitable meat option for } \\
\text { vegetarians }\end{array}$ & & & & & \\
\hline $\begin{array}{l}\text { Cultured meat would be } \\
\text { more ethical than } \\
\text { conventional meat }\end{array}$ & & & & & \\
\hline
\end{tabular}

15. Do you think cultured meat would be a premium product or an inferior product to conventional meat?*

Mark only one oval.

Inferior-it would cost less than conventional meat

Premium product- it would cost more than conventional meat

I dont know 
16. Do you think cultured meat will be able to produce the same flavour and texture as conventional meat?*

Mark only one oval.

Attitudes of

rural and urban

Yes

consumers

No

Maybe

17. From focus group research, the following CONCERNS were raised by Irish consumers about cultured meat. Please rate these from 1-5 in the order which you think are of greatest concern (e.g. select 1 for what would concern you the most, 2 for your next biggest concern, etc..) NOTE: you can only select each number once *

Mark only one oval per row.

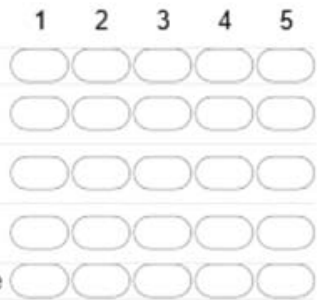

18. The following points were raised by Irish consumers as the possible BENEFITS of cultured meat. Please rate from 1-5 the order which you think would be the most important benefits (e.g. select 1 for what you think would be the biggest potential benefit, 2 for the next most important potential benefit, etc..) *

Mark only one oval per row.

\section{$\begin{array}{lllll}1 & 2 & 3 & 4 & 5\end{array}$}

Animal welfare (animals wont

need to be killed to produce meat)

Environmental benefits (reduction

in greenhouse gases, help solve global warming)

Antibiotic and hormone free meat

Nutritionally controlled meat

(tightly controlled fat/protein

content etc)

Way of "feeding the world" (lasting

supply of meat, meat more

accessible to all)

19. What category does your occupation fall into? *

Mark only one oval.

Self employed/ Freelance

Farmer 
$\mathrm{BFJ}$ 121,8

\section{White collar worker/ Civil servant}

Housewife/ Househusband

Skilled workers

Student

Pensioner

Currently without work

Other:

20. Please tick box below which is closest to your disposable income per week (Disposable income is the total amount of income you have available after main expenses have been paid) *

Mark only one oval.

$€ 50$

$€ 100$

$€ 150$

$€ 200+$

\section{About the authors}

Elaine Shaw graduated from the MSc Culinary Innovation and New Product Development from the School of Culinary Arts \& Food Technology, Dublin Institute of Technology with first class honours in 2017. She is currently working in the food and drinks industry in Aukland, New Zealand.

Dr Máirtín Mac Con Iomaire is Senior Lecturer in the School of Culinary Arts \& Food Technology, Dublin Institute of Technology (DIT), Ireland. He is an award winning chef, food historian, broadcaster, culinary educator and ballad singer. He is the co-founder and chair of the biennial Dublin Gastronomy Symposium and is trustee of the Oxford Symposium on Food and Cookery. He supervises a cohort of doctoral research students investigating various aspects of Ireland's culinary heritage and current gastronomic practice. He is Chair of the Masters in Gastronomy and Food Studies in DIT, the first such programme in Ireland. He is Co-editor with Eamon Maher of "Tickling the Palate": Gastronomy in Irish Literature and Culture (Peter Lang: 2014). Dr Máirtín Mac Con Iomaire is the corresponding author and can be contacted at: mairtin.macconiomaire@dit.ie

For instructions on how to order reprints of this article, please visit our website: 